\title{
Developing Professional Skills at Tertiary Level: A Model to Integrate Competencies across the Curriculum
}

\author{
Fermín Sánchez, Antonia Soler, David López, Carme Martín, Alicia Ageno, Luís Belanche, Jose Cabré, Erik Cobo, \\ Rafel Farré, Jordi García, Pere Marès \\ Universitat Politècnica de Catalunya - BarcelonaTech \\ c/Jordi Girona 1 i 3, Campus Nord UPC, Mòdul B6, 08034 Barcelona \\ fermin@ac.upc.edu, antonia.soler@upc.edu, david@ac.upc.edu, martin@essi.upc.edu, ageno@1si.upc.edu, belanche@1si.upc.edu, \\ jose.cabre@upc.edu, erik.cobo@upc.edu, rafel.farre@upc.edu, jordig@ac.upc.edu, pere.mares@upc.edu
}

\begin{abstract}
In the context of the European Higher Education Area, curriculum design needs to be based on the defined competencies of each degree programs, including both domainspecific and professional competencies. In this educational context, developing students' professional skills poses a new challenge we need to face. The present work proposes a model to globally develop professional skills in an Engineering degree program. Based on competency maps, this model allows careful analysis, revision and iteration for an effective integration of professional skills. We define each competency in terms of "dimensions" (or sub-skills), which are further defined according to three-level objectives. Competency maps are built showing the specific graded objectives, which allows to integrate them most finely into degree subjects. A global competency map is also designed including the objectives to be achieved throughout the degree. This global map becomes a useful tool for curriculum designers and coordinators. It allows them to optimize the workload, and to make adjustments most effectively, helping students develop the defined competencies as a global comprehensive experience. To illustrate our model, we explain how it has been implemented to integrate "Communication skills" into subjects, and how the model has been applied to assess "Appropriate attitude towards work" skills.
\end{abstract}

Keywords-professional skills; competency; competency map; competency dimensions

\section{The NeED to DEVElop Professional SKILLS}

Prior to the creation of the European Higher Education Area (EHEA), university curricula focused on the development of domain-specific competencies, without paying much attention to professional skills. These competencies were only included occasionally in some subjects, and were rarely assessed in engineering curricula. Exceptionally, some master programmes did focus on professional skills (like MBA curricula), since it was assumed that these abilities were crucial in the profession. This situation was common to both European and American universities.

This trend began to change in 2000, when the Department of Aeronautics and Astronautics at the MIT started the CDIO (Conceive, Design, Implement \& Operate) project, an initiative to encourage the development of abilities required in real-world engineering situations [1]. Other universities and departments quickly joined this initiative, such as Chalmers, KTH, LiU, DTU or USNA.

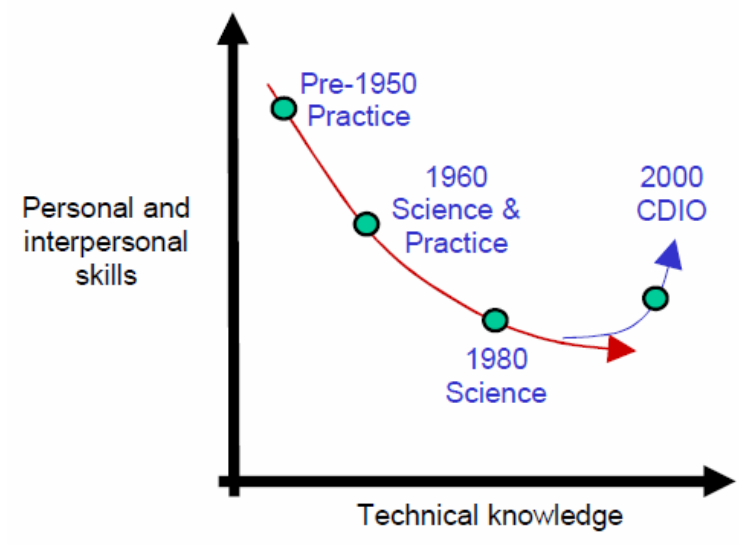

Fig 1. CDIO Objective

The CDIO project started after a thorough analysis of some weaknesses found in university contents and practice. It had been observed that there was an important gap between industry requirements and the contents of engineering curricula. After World War II, most university lecturers in American universities had previously been industry professionals who could bring their industry awareness to their teaching practice. However, universities progressively concentrated their efforts on research activities, and domainspecific contents became the focus in syllabuses. As more time and effort was devoted to these contents, other more practical aspects were left aside, like students' personal and interpersonal skills. Therefore, the objective of the CDIO initiative was to foster students' personal abilities while domain-specific contents were maintained (as shown in Fig. 1).

The first step towards an integrative curriculum was to study industry quality standards in order to identify a set of relevant competencies. The CDIO project studied MIT 
standards and those established by other universities and companies (such as Boeing), as well as widely-recognized criteria like those set by the ABET [2]. In addition, a largescale survey was carried out among industry engineers, faculty members and quality agencies to gather their opinions about the competencies that graduates should develop before entering the profession. The result of this extensive study was an agreed-upon set of competencies to be included in the new curricula of those institutions participating in the CDIO project. These competencies and skills were grouped into four categories as follows:

\section{Technical knowledge and reasoning skills}

2. Personal and professional skills and attributes

3. Interpersonal skills, teamwork and communication

4. Design, implementation and operation skills in the enterprise and societal contexts

As the CDIO initiative started in the USA, in Europe, the Tuning project was created with similar objectives. Led by the University of Deusto, the project was supported by more than one hundred European universities. Just like the CDIO initiative, Tuning carried out a survey among industry partners, faculty members and graduates to list the relevant competencies of each discipline, and to design curricula extension. The Tuning project focuses on the design of a methodology that favours curriculum understanding and standardization among universities. This involves a dynamic process of continuous revision and refinement in accordance with social needs, where the ideas of "learning outcome" and "competency" are introduced. The first result of this project was a standard to define generic (professional) competencies in the context of the EHEA, which was extended to Latin America [3].

The work developed in the first phase of the project defined thirty professional competencies that would be common to the programmes included in the study, and a list of specific competencies for each discipline. The thirty competencies were classified into three categories: instrumental (10), interpersonal (8) and systemic (12). All competencies were defined in depth in a report that was adopted by the institutions intending to integrate professional competencies in their curricula.

\section{PROFESSIONAL SKILLS IN ENGINEERING CURRICULA}

In the EHEA, curricula are designed in accordance with the Tuning project, on the basis of competencies and following the requirements set by institutions [4]. In this context, an approach to develop professional skills in an engineering curriculum could include the design of specific courses. However a more integrative, global approach can be implemented where professional skills are distributed into different degree courses, as in the case of domain-specific competencies. Assigning competencies to degree subjects requires setting up levels and coordinating the work carried out in different courses for a given competency.

While this approach is being explored in engineering curricula, it is a new, complex task that requires careful planning, as reported in [5]. Indeed, most faculty members in undergraduate and master programmes have little experience in developing professional skills, so they find it difficult to include them in their courses. Some of the professional competencies may even be considered more difficult to include than others, and lecturers might find it easier to integrate "Communication skills" or "Teamwork skills" than "Ethical sense and commitment skills", for example.

In order to attempt the integration of professional competencies into degree courses, a hierarchical approach has been suggested in [6], based on Bloom's taxonomy [7]. This method defines each competency in terms of three-level objectives, based on the "knowledge", "comprehension", and "application" stages. Each level could be assigned to one or more courses. It is also suggested that level 1 of each competency is developed in first-year courses. Then, level 2 is started in the second year and completed in the third and fourth years together with level 3 , according to the specific objectives of each degree. Fig. 2 illustrates this method in a diagram, where each box represents one subject or course. This proposal also suggests that a competency coordinator should help course designers and lecturers to design activities for practice and assessment in order to make the most of this integration.

As a starting point, this method seems to provide tools for curriculum designers to integrate professional skills into degree subjects effectively, but in practice it is not flexible enough. On the one hand, this approach allows to define competency contents and assign them to degree courses, and to coordinate the development of each competency throughout the degree studies. It is possible to set competency itineraries where participants become aware of levels, objectives, contents and the subjects where they are integrated, as shown in Fig. 3. On the other hand, we have observed that defining a competency directly into levels does not allow for the detail and flexibility we need to integrate competency contents most appropriately. Therefore we present a model that helps us refine the process of defining competencies and then allows us to assign objectives more accurately.

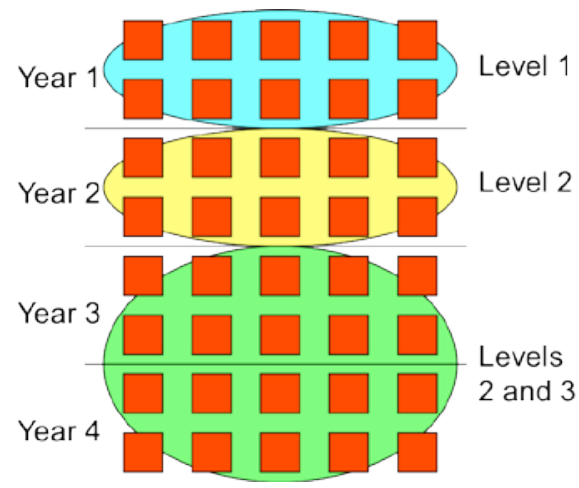

Fig. 2. Competency levels in academic years 


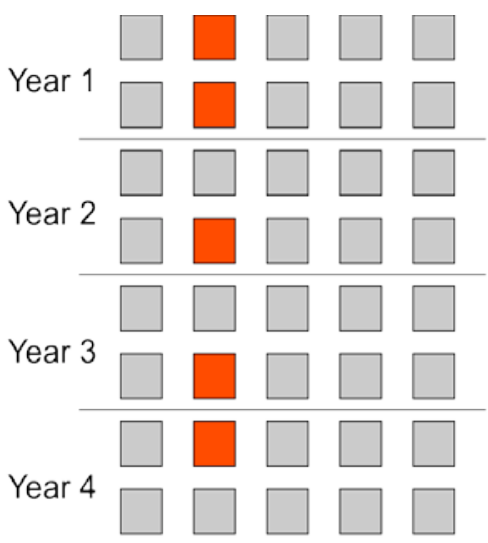

Fig. 3. Example of competency itinerary

\section{A MODEL TO INTEGRATE PROFESSIONAL SKILLS: COMPETENCY MAPS}

In order to design a model to develop professional skills, one of our initial considerations was the framework set by Universitat Politècnica de Catalunya. The following group of professional skills has been defined and has to be incorporated in all the university degrees:

- Entrepreneurship and innovation

- Sustainability and social commitment

- Foreign language skills

- Communication skills

- Teamwork skills

- Information search and management

- Autonomous Learning

The university has also issued a guide with recommendations on how to integrate these competencies in degree programs. The procedure they recommend is based on the three-level model described above, according to Bloom's taxonomy. However, each department and school can adapt this model to integrate those competency levels most appropriately in their curricula.

The Barcelona School of Informatics has first defined a list of nine professional competencies and then developed a procedure to integrate them. The list includes the seven competencies above, and two more competencies for the Bachelor Degree in Computing Engineering:

- Appropriate attitude towards work

- Reasoning skills

The procedure includes assigning a coordinator to each competency, and setting up a team of coordinators to work on the integration of the nine professional competencies. Working in this group, and sharing the experience for each competency, is helping us to have a global view of this integration to make improvements for better practice.

\section{A. The competency map}

As mentioned above, our starting point was the university proposal, but we decided to revise some aspects after its first implementation. We had defined the contents of each competency into three levels, which resulted in general sequenced objectives that were too extensive to be included in one subject. We realized that these objectives were also difficult to split to be assigned to more than one subject. Thus, after evaluating the first results, we realized that we needed to revise this initial approach to integrate professional skills into the degree subjects.

As we were working on the contents of the different competencies, we agreed that we could make competency objectives more specific and more flexible for a more appropriate integration. We decided that for the nine competencies we could set up a list of sub-skills (or dimensions), and define three-level objectives for each dimension. This approach resulted in a competency map in which specific objectives were clearly defined for the corresponding sub-skills and levels, as shown in Fig. 4.

The objectives set for each level in the competency map may not coincide exactly with the first three levels in Bloom's taxonomy, but in most cases this is the basis for grading them. In general, level 1 could correspond to the "knowledge" stage, the objectives in level 2 could be associated to the "comprehension" stage, and level 3 would be concerned with the "application" stage. In order to illustrate this grading, Fig. 5 shows how objectives and levels have been defined for one dimension in the case of "Foreign language skills". We can see that in order to practice listening skills in an engineering context, the first level focuses on developing basic skills to understand a message. Later, level 2 is devoted to understanding how communication strategy is applied as listening to different oral genres is practiced. Finally, in level 3 , application is required as communicative strategy and efficiency are assessed.

\begin{tabular}{|c|c|c|c|}
\hline $\begin{array}{c}\text { Professional } \\
\text { Competency }\end{array}$ & $\begin{array}{c}\text { Objectives } \\
\text { level 1 }\end{array}$ & $\begin{array}{c}\text { Objectives } \\
\text { level 2 }\end{array}$ & $\begin{array}{c}\text { Objectives } \\
\text { level 3 }\end{array}$ \\
\hline dimension 1 & & & \\
\hline dimension 2 & & & \\
\hline$\ldots$ & & & \\
\hline dimension n & & & \\
\hline
\end{tabular}

Fig. 4. A competency map 


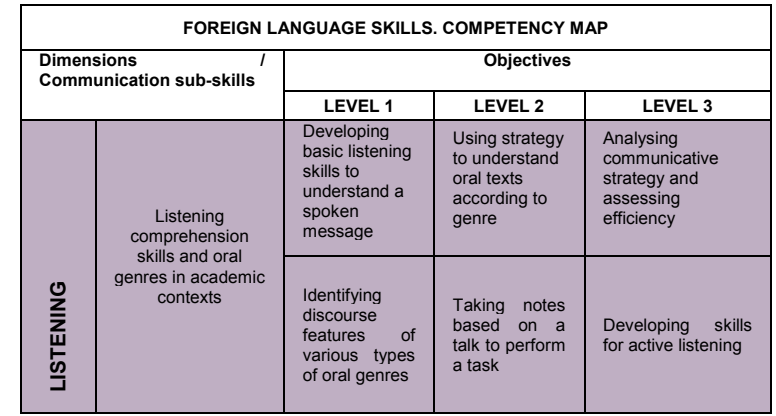

Fig. 5. Foreign language skills: example of dimension and levels

This model based on maps allows flexible integration of specific competency objectives, which can also contribute to increasing students' awareness of professional skills. These objectives are defined according to dimension and level so that we can assign them to subjects most appropriately and we avoid handling complete levels. For example, one of the subjects in the first year could be assigned only one of the objectives (boxes) in the table above for level 1, while another subject could include another objective at the same level. In subsequent years and subjects, different levels and objectives can also be combined. Students are thus more aware of the specific objectives they have to attain, which can promote reflection on the progress they need to make to develop professional skills [8].

Additionally, our model allows to combine and integrate specific objectives and dimensions. This is possible when various dimensions and objectives are related or fit appropriately in the contents of a course. This is shown in Fig. 6 , where the colored boxes represent how some objectives and levels of several dimensions have been assigned to one subject. Our model becomes flexible enough to integrate objectives at one or more levels into the same subject, to assign objectives of various dimensions at the same level, and even to avoid assigning objectives of some dimensions if convenient. This flexibility is allowed for domain-specific competencies, and it also seems to be appropriate for professional skills.

\begin{tabular}{|c|c|c|c|}
\hline $\begin{array}{c}\text { Professional } \\
\text { Competency } \text { X }\end{array}$ & $\begin{array}{c}\text { Objectives } \\
\text { level 1 }\end{array}$ & $\begin{array}{c}\text { Objectives } \\
\text { level 2 }\end{array}$ & $\begin{array}{c}\text { Objectives } \\
\text { level 3 }\end{array}$ \\
\hline dimension 1 & & & \\
\hline dimension 2 & & & \\
\hline dimension 3 & & & \\
\hline dimension 4 & & & \\
\hline dimension 5 & & & \\
\hline dimension 6 & & & \\
\hline dimension 7 & & & \\
\hline dimension 8 & & & \\
\hline
\end{tabular}

Fig. 6. Dimensions and objectives assigned to one course
Furthermore, our proposal offers a tool to control competency itineraries. As shown in Fig. 7, we can visualize the subjects to which dimensions, levels and objectives are assigned for a particular competency. In this example, subject $\mathrm{S} 1$ represents the integration of objectives in Fig. 6 for a given competency. We can also see how other dimensions and levels of that competency are assigned to other courses (S2-S5).

These itineraries help curriculum designers to adjust this integration most conveniently when necessary. As displayed in Fig. 7, this map proves to be very useful to check how objectives are assigned throughout the degree, how some may be recurrent and how some may not be covered. This may occur when curriculum design states that a specific dimension and level is not to be developed in a particular degree. Indeed, the specific curriculum has to define the levels to be covered for each professional competency, and accordingly, the map may show some blank boxes. Some higher-level objectives could be more appropriately attained in master programs, for example, while some lower-level objectives could be left out of the map.

\begin{tabular}{|c|c|c|c|}
\hline $\begin{array}{c}\text { Professional } \\
\text { Competency X }\end{array}$ & $\begin{array}{c}\text { Objectives } \\
\text { level 1 }\end{array}$ & $\begin{array}{c}\text { Objectives } \\
\text { level 2 }\end{array}$ & $\begin{array}{c}\text { Objectives } \\
\text { level 3 }\end{array}$ \\
\hline dimension 1 & S1 & S2 & S2 \\
\hline dimension 2 & S1 & S1, S3 & S1 \\
\hline dimension 3 & S1 & S1 & S1 \\
\hline dimension 4 & S2 & S4 & S1, S4 \\
\hline dimension 5 & S3 & S3 & S4 \\
\hline dimension 6 & S2 & S1, S2 & S1 \\
\hline dimension 7 & S1 & S3 & S3, S5 \\
\hline dimension 8 & S3 & S5 & S5 \\
\hline
\end{tabular}

Fig. 7. Itinerary of a competency in the curriculum

\begin{tabular}{|c|c|c|c|c|}
\hline & $\begin{array}{c}\text { Professional } \\
\text { Competency } \\
\mathbf{1}\end{array}$ & $\begin{array}{c}\text { Professional } \\
\text { Competency } \\
2\end{array}$ & $\begin{array}{c}\text { Professional } \\
\text { Competency }\end{array}$ & $\begin{array}{c}\text { Professional } \\
\text { Competency } \\
\mathbf{3}\end{array}$ \\
\hline dimension 1 & $\mathrm{X}$ & & & $\mathrm{X}$ \\
\hline dimension 2 & $\mathrm{X}$ & & & \\
\hline dimension 3 & & $\mathrm{X}$ & & \\
\hline dimension 4 & & $\mathrm{X}$ & $\mathrm{X}$ & \\
\hline dimension 5 & & & $\mathrm{X}$ & \\
\hline dimension 6 & & & $\mathrm{X}$ & \\
\hline dimension 7 & & & $\mathrm{X}$ & \\
\hline dimension 8 & $\mathrm{X}$ & & & $\mathrm{X}$ \\
\hline dimension 9 & & & & $\mathrm{X}$ \\
\hline dimension 10 & & & & $\mathrm{X}$ \\
\hline
\end{tabular}

Fig. 8. Map of dimensions and competencies in the curriculum

\section{B. The global competency map}

The global competency map is a matrix that combines the maps of all nine competencies in order to provide a picture of the complete development of professional skills. Again, this becomes a useful tool in our model that provides further information for all designers and coordinators to optimize workload. First, we need to define all dimensions, and the 
corresponding three-level objectives to identify partial or complete redundancies across competencies. Then, if we identify overlapping objectives, we may decide whether it is necessary to avoid those redundancies. In fact, after constructing our first global map for the Bachelor Degree in Computing Engineering, we realized that some competencies shared objectives. Therefore, we decided to carry out a second iteration to simplify the map where necessary. Fig. 8 shows how this is made apparent in the global map, and how the map can help us start revisions as necessary (level objectives have been omitted to simplify the figure).

Some of the coincidences we identified in our global map were actually handled in different ways. In some cases, we decided that it was necessary to simplify the map and fuse objectives. This is the case of coincidence found between "Communication skills" and "Teamwork skills". We found that a dimension named "interpersonal communication" was listed in the maps of both competencies, with shared objectives. In this case, we decided that this practice was redundant and it would be more efficient to assign other objectives.

However, we found it appropriate to maintain objectives and some overlapping practice in other cases. For example, some of the objectives of "Communication skills" may show some coincidence with those defined for "Foreign language skills", since both share some objectives to develop writing and oral communication skills. But we understand that objectives need to be maintained in each competency since they are approached differently. In addition, it is also true that recurrent practice proves to be effective in the development of competence and ability in general, which may reinforce our decision. Another example where we did not find it convenient to fuse objectives was the case of coincidence between "Teamwork skills" and "Entrepreneurship and innovation". They share a dimension named "decision making and problem solving". In this case, we could observe that in spite of overlapping, the objectives set for "Teamwork skills" were more specific, and so we decided that it would be effective to maintain them in both competencies.

\begin{tabular}{|c|c|c|c|c|c|c|c|c|c|c|c|c}
\hline & \multicolumn{2}{c|}{$\begin{array}{c}\text { Professional } \\
\text { Competency 1 }\end{array}$} & \multicolumn{3}{c|}{$\begin{array}{c}\text { Professional } \\
\text { Competency 2 }\end{array}$} & \multicolumn{3}{c|}{$\begin{array}{c}\text { Professional } \\
\text { Competency 3 }\end{array}$} & \multicolumn{3}{c}{$\begin{array}{c}\text { Professional } \\
\text { Competency 4 }\end{array}$} \\
\hline & L1 & L2 & L3 & L1 & L2 & L3 & L1 & L2 & L3 & L1 & L2 & L3 \\
\hline dimension 1 & & & & & & & & & & & & \\
\hline dimension 2 & & & & & & & & & & & & \\
\hline dimension 3 & & & & & & & & & & & & \\
\hline dimension 4 & & & & & & & & & & & & \\
\hline dimension 5 & & & & & & & & & & & & \\
\hline dimension 6 & & & & & & & & & & & & \\
\hline dimension 7 & & & & & & & & & & & & \\
\hline dimension 8 & & & & & & & & & & & & \\
\hline dimension 9 & & & & & & & & & & & & \\
\hline dimension 10 & & & & & & & & & & & & \\
\hline
\end{tabular}

Fig. 9. Global competency map

All these decisions can be shown in our global map, where we can specify the results of our revisions. As shown in Fig. 9, our global competency map displays the three-level objectives for each dimension and competency. According to their descriptors, we can identify those coincidences and take decisions, as we show changes in the map. We can keep record of all this procedure for curriculum design, making our map a very useful tool for present and future work.

\section{Procedures and general results}

As we mentioned above, and as suggested in [6], in order to shape the integration professional skills, it is necessary to coordinate all the procedure to help participants. At the Barcelona School of Informatics, a coordinator was appointed for each competency, and a team was also set up to bring the coordinators together under the supervision of a general team coordinator. Each coordinator was in charge of defining competency contents and dimensions, and assigning specific objectives to subjects, according to a previous selection of subjects. Work was started with the corresponding course coordinators, and the competency group met regularly to report on the progress made, to share implementation strategies and to take decisions about common procedures.

After defining the contents of each competency, we started the first implementation, which consisted in a common procedure to integrate skills in the subjects. Competency coordinators organized meetings with course coordinators in order to discuss how competency contents could best fit in their course syllabuses. This included discussing objectives, designing effective practice activities, and taking decisions about assessment methods. These first contacts showed that in general, course coordinators and lecturers needed some guidance to implement the professional competencies assigned. More specifically, for some competencies and subjects, although this guidance was necessary, integration could be planned quite naturally in the course syllabus, whereas in other cases a specific competency was very difficult to implement because it did not fit appropriately into course contents. In the latter cases, we decided to abandon the integration of a competency and maybe reassign a more appropriate one, with the corresponding adjustments in other subjects and competencies.

After we received the first feedback, we thus decided that it was necessary to make some general adjustments as convenient. Firstly, we reassigned competencies and objectives in a few cases so that coordinators felt comfortable with integrating those objectives. In general most subjects are assigned to develop and evaluate one or two competencies, up to three in the case of subjects based on project development. Secondly, after coordinators shared the feedback received, it was possible to design a global strategy for the implementation of all competencies. This included designing our competency map and planning effective iteration with the corresponding course coordinators for a finely tuned implementation. Finally, we also decided to validate the results attained by submitting to peer review all the reports issued by competency coordinators [9].

The outcome of all this process is our proposed model to integrate professional competencies in the Bachelor Degree in Computing Engineering curriculum. We have defined nine competency maps and a global competency map that 
constitute a useful tool for curriculum design. These maps allow to implement a procedure to integrate professional skills which is based on iteration and refined improvement.

\section{AN EXAMPLE OF COMPETENCY INTEGRATION: COMMUNICATION SKILLS}

While communication is one of most demanded professional competencies in the engineering professions, it seems to be a noticeable weakness of graduates in general. A study published in 2004 [10] revealed some general conclusions about graduates' communication skills that should be taken into consideration:

- Communication skills are essential for engineers' professional success.

- A great gap can be observed between the communication skills required by engineering professions and the skills exhibited by graduates.

- Communicative skills are not effectively developed in engineering curricula.

This seems to be the situation for university graduates in Spain. It has been observed that they lack effective communication skills, and at the same time, engineering curricula do not include the development of communication skills (and professional skills in general).

In order to move towards improving students' communication skills, and according to our model to develop professional competencies, we have applied the procedure to integrate "Communication skills" in the Bachelor Degree in Computing Engineering. The competency map has been designed, defining dimensions and objectives, and work has been planned and started to implement the integration in various degree subjects.

We have defined "Communication skills" as the capacity to transmit ideas to a given audience, exchange opinion, persuade the audience, interact in dialogue, participate actively and constructively in debate, exchange ideas in teamwork, and use communication tools appropriately for effective communication. In order to make this definition more specific to respond to students' needs, we have identified 8 dimensions that allow to grade competency objectives at three levels:

- Using visuals

- Synthesizing skills

- Building argument, reasoning and summarizing

- Building example, metaphor and comparison

- Writing reports

- Making presentations

- Discussing, negotiating and brainstorming

- Interpersonal communication (active listening and assertive communication)

Three levels based on Bloom's taxonomy have been identified to grade dimension objectives:

- Level 1. Gaining basic knowledge and awareness of communication skills, and sub-skills (dimensions). Recognizing these dimensions in different communication activities. Participating in communicative situations, identifying the sub-skills involved.

- Level 2. Recognizing basic sub-skills in a given communicative situation. Identifying strong and weak points, and suggesting improvement. Participating in communicative situations, analyzing effectiveness critically.

- Level 3 Applying strategy for effective communication. Participating in communicative situations effectively and creatively.

These dimensions and levels have allowed us to design a map with the specific objectives to be integrated in degree subjects (the complete detailed map can be found in [11]).

With the purpose of illustrating how objectives have been defined, we analyze one of the dimensions identified, i.e. "using visuals". Visuals are used mainly to convey information in an intuitive, structured way. Students should be able to select an appropriate type of visual to display information most effectively, since this is crucial to transmit specific data clearly. The following objectives have been defined for the three levels:

- Level 1 (knowledge). Becoming aware of types of visuals types and explaining their common uses.

- Level 2 (comprehension). Identifying the relevant information in a given visual. Recognizing redundant detail and suggesting improvement.

- Level 3 (application). Selecting an appropriate visual to represent and transmit a given set of data according to genre, purpose and audience. Implementing the visual.

Following the procedure devised in our model, we have assigned "Communication skills" objectives to fourteen degree subjects and to the final degree thesis. The objectives for levels 1 and 2 are integrated in first-year subjects, while higher objectives are better integrated in subsequent years. Subjects include compulsory and optional subjects. The competency coordinator arranged meetings with course coordinators in order to discuss integration strategy. In some cases, seminars were organized for course coordinators and lecturers to help them design activities for practice and assessment, as well as evaluation rubrics. The competency coordinator even attended several lectures as scheduled to monitor practice and provide specific help.

Our competency map for "Communication skills" has allowed us to cover skills and sub-skills as needed by our undergraduate students [12]. First, we have selected dimensions that include oral, writing and interaction skills without leaving crucial objectives aside. In addition, we have covered low-level objectives, to allow the inexperienced student to cope with them. Finally, we have graded objectives so that an appropriate sequence is followed when necessary while other objectives are more effectively achieved in parallel. This requires careful planning of competency development. 


\section{AN EXAMPLE OF COMPETENCY ASSESSMENT: APPROPRIATE ATTITUDE TOWARDS WORK}

The main idea underlying the implementation of "Appropriate attitude towards work" is to identify the academic parameters needed to generally strengthen professional skills. During their academic life, students should improve the following skills: the ability to work in teams with responsibility and respect; a proactive attitude towards work; motivation for quality, continuous improvement and professional achievement; the ability to adapt to organizational and technological changes; the capacity to work in situations with lack of information and resource constraints; the capacity for personal integration in an industrial environment; and the capacity for rigorous professional development.

All these skills have been summarized in the nine dimensions identified for the "Appropriate attitude towards work" competency map:

- Efficient management of working time

- Respect

- Rigor in achieving the technical competencies of the course

- Motivation

- Ability to identify shortcomings and weaknesses

- Responsibility in learning

- Active interest in obtaining quality results

- Capacity to adapt to organizational and technological changes

- Professional fulfillment

These dimensions and the corresponding graded objectives were assigned to degree subjects, and implementation strategy was planned. In accordance with the strategy proposed in our model, the competency coordinator defined a set of activities for competency development and assessment. The nine dimensions and the proposed activities for each level have been explained in detail in [13].

In order to illustrate how these activities were planned, Fig. 9 shows the activities selected for the Databases course.

\begin{tabular}{|c|c|c|c|}
\hline Dimension & Level 1 Knowledge & Level 2 Comprehension & Level 3 Application \\
\hline Efficient management of working time & $\begin{array}{l}\text { Short question at the } \\
\text { beginning of the class }\end{array}$ & $\begin{array}{c}\text { Teamwork with cooperative learning } \\
\text { techniques }\end{array}$ & \\
\hline Respect & \begin{tabular}{|c|}
$\begin{array}{c}\text { Teamwwork with cooperative } \\
\text { learning techniques }\end{array}$ \\
\end{tabular} & & \\
\hline $\begin{array}{l}\text { Rigor in achieving the technical } \\
\text { competencies of the course }\end{array}$ & & Pass all the computer tests proposed & \\
\hline Motivation & $\begin{array}{c}\text { Teamwork with cooperative } \\
\text { learning techniques }\end{array}$ & & \\
\hline $\begin{array}{l}\text { Ability to identify shortcomings and } \\
\text { aspects to improve }\end{array}$ & \begin{tabular}{|c|}
$\begin{array}{c}\text { Teamwork with cooperative } \\
\text { learning techniques }\end{array}$ \\
\end{tabular} & Group review & \\
\hline Responsibility in learning & & $\begin{array}{c}\begin{array}{c}\text { Autonomous learning work for } \\
\text { theory, exercise or laboratory classes }\end{array} \\
\end{array}$ & \\
\hline Active interest in obtaining quality results & Understanding rubrics & & \\
\hline $\begin{array}{c}\text { Capacity to adapt to organizational and } \\
\text { technological changes } \\
\end{array}$ & & & $\begin{array}{c}\text { Exercises with time and } \\
\text { resources constraints }\end{array}$ \\
\hline Professional realization & & & \\
\hline
\end{tabular}

Fig. 9. Activities for the Databases course

After planning these activity types, a file based on a template was created to design each activity. Fig. 10 shows the "short question at the beginning of the class" activity.

\begin{tabular}{|c|c|}
\hline Activity: & Short-question at the beginning of a theory session \\
\hline Activity description & $\begin{array}{l}\text { At the beginning of a theory session, the lecturer hands out a } \\
\text { question about an autonomous-learning task performed as } \\
\text { homework. Students answer the question in a separate sheet and } \\
\text { submit it. Answers are discussed in class. }\end{array}$ \\
\hline Activity objective & $\begin{array}{l}\text { Checking students' responsibility and commitment to perform the } \\
\text { autonomous work assigned. Assessment and punctuality are also } \\
\text { assessed indirectly. }\end{array}$ \\
\hline Competency & Appropriate attitude towards work \\
\hline Other competencies & Autonomous learning \\
\hline \multicolumn{2}{|l|}{ Task description } \\
\hline $\begin{array}{l}\text { Lecturer's tasks in and } \\
\text { outside the class to carry out } \\
\text { the activity }\end{array}$ & $\begin{array}{l}\text { - The lecturer prepares a question. } \\
\text { - The lecturer hands out the question in class. } \\
\text { - The lecturer assesses students' answers. } \\
\text { - The teacher guides some discussion about students' answers. }\end{array}$ \\
\hline Students' tasks in class & - The student answers the question in writing and submits it. \\
\hline $\begin{array}{l}\text { Students' tasks outside the } \\
\text { class }\end{array}$ & $\begin{array}{l}\text { The student enters the virtual class and completes the } \\
\text { autonomous-leaming assignment. The student takes notes } \\
\text { about his/her own performance. }\end{array}$ \\
\hline \multicolumn{2}{|l|}{ Activity timing } \\
\hline $\begin{array}{l}\text { Estimated time for lecturer's } \\
\text { tasks }\end{array}$ & $\begin{array}{l}\text { FIRST TIME } \\
\text { Preparing the question: } 15 \text { minutes } \\
\text { Assessing the answers submitted by about } 30 \text { students, and taking } \\
\text { notes for class discussion: } 3 \text { hours } \\
\text { EVERY TIME ACTIVITY IS PERFORMED } \\
\text { If the same question is used: } 0 \text { minutes } \\
\text { If a new question is prepared: } 15 \text { minutes } \\
\text { Assessing the answers submitted by about } 30 \text { students, and taking } \\
\text { notes for class discussion: } 3 \text { hours }\end{array}$ \\
\hline $\begin{array}{l}\text { Estimated time for students' } \\
\text { tasks in class }\end{array}$ & Answering the question: 5 minutes \\
\hline $\begin{array}{l}\text { Estimated time for students' } \\
\text { tasks outside the class }\end{array}$ & $\begin{array}{l}\text { Completing the autonomous-learning assignment and taking } \\
\text { notes: } 2 \text { hours }\end{array}$ \\
\hline \multicolumn{2}{|l|}{ Activity materials } \\
\hline Students' materials & Student's individual notes about his/her own autonomous work \\
\hline \begin{tabular}{|l|} 
Lecturer's materials \\
\end{tabular} & Question to hand out \\
\hline $\begin{array}{l}\text { Necessary conditions to } \\
\text { develop the activity: students, } \\
\text { lecturers, room, etc. }\end{array}$ & $\begin{array}{l}\text { - Group size: } 20 \text { to } 40 \text { students for appropriate task completion } \\
\text { - Room: Ordinary, with ordinary equipment (blackboard) } \\
\text { - Students should be willing to participate }\end{array}$ \\
\hline \multicolumn{2}{|l|}{ Assessment } \\
\hline Assessment parameters & $\begin{array}{l}\text { The answer submitted by the student in the first } 5 \text { minutes allows } \\
\text { to assess: attendance, punctuality, rigor, responsibility }\end{array}$ \\
\hline $\begin{array}{l}\text { Parameter assessment } \\
\text { method }\end{array}$ & $\begin{array}{l}\text { Formative assessment } \\
\text { The student has submitted an answer that can be compared to the } \\
\text { correct answer issued by the lecturer. }\end{array}$ \\
\hline Assessment instruments & $\begin{array}{l}\text { The lecturer marks students' answers and he/she makes comments } \\
\text { on wrong answers. }\end{array}$ \\
\hline Degree course and contents & $\begin{array}{l}\text { Any degree course and contents are appropriate to perform this } \\
\text { activity }\end{array}$ \\
\hline Other c & \\
\hline
\end{tabular}

Fig. 10. Example of an activity file

As a result of the application of these activities, we obtained the first assessment results, which are shown as follows. Firstly, Fig. 11 displays the table used to calculate students' grades. Grade A means Very good, B means Good, C means Pass, D means Fail and NA stands for Not applicable. Secondly, Fig. 12 presents the grades students obtained in the Databases course from 2010-2011 to 2012-2013, showing autumn semesters (AS) and spring semesters (SS).

\begin{tabular}{|l|lccccccccc|}
\hline \multicolumn{10}{c}{ THEORY/EXERCICES } & \multicolumn{1}{c}{ LABORATORY } \\
Name & Group & Act1 & Act2 & Act3 & T/E GRA & Act1 & Act2 & Act3 & LGRADE & GRADE \\
\hline Student 1 & G11 & A & A & A & A & A & A & A & A & A \\
Student 2 & G11 & A & A & B & A & A & A & A & A & A \\
Student 3 & G11 & A & B & C & C & A & A & A & A & B \\
Student 4 & G11 & A & B & B & B & A & A & A & A & B \\
Student 5 & G11 & D & D & NA & NA & D & & D & NA & NA \\
Student 6 & G11 & C & C & D & D & B & A & A & A & C \\
Student 7 & G11 & D & C & D & D & B & B & B & B & D \\
\hline
\end{tabular}

Fig. 11. Table to calculate the competency grades of the Databases course 


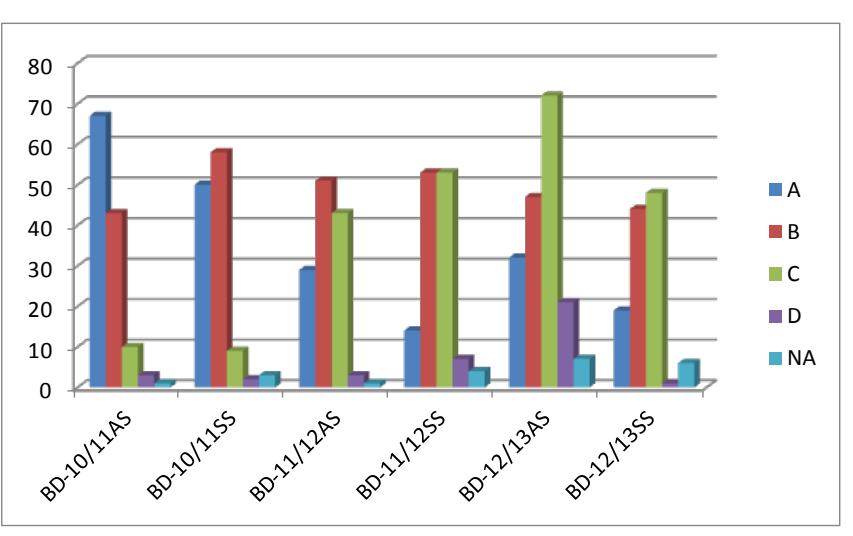

Fig. 12. General competency grades in the Databases course

The first implementation (year 2010-2011) shows a clear tendency to higher grades. This is probably due to the lack of lecturers' experience in assessing generic competencies. However, after having solved some problems found during this period with the help of the competency coordinator, the subsequent years show some grade normalization. The number of $\mathrm{B}$ and $\mathrm{C}$ grades is higher than that of A grades.

Besides these quantitative results, some qualitative data has also been collected. In the SS of 2012-2013, 93 students in the Databases course answered a short questionnaire to give a rated opinion about the acquisition of the competency. The questionnaire statements included the following:

- Teamwork, with cooperative learning techniques, helps me to become proactive and respectful with my teammates.

- Teamwork, with cooperative learning techniques, improves my positive interdependence.

- A short question at the beginning of the class encourages my attendance and punctuality.

- Autonomous learning makes me more responsible.

- The use of rubrics helps me to improve rigor and quality. The answers were selected according to the following rating: 1 (completely disagree), 2 (disagree), 3 (partially agree), 4 (agree) and 5 (completely agree).

The average result of the questionnaire answers was higher than 3 for all the statements. This corroborates that students are satisfied with the activities devised for competency development. It also confirms that they are aware of improvement in their attitude. More details of this study can be found in [13].

\section{CONCLUSIONS}

The need to develop professional skills in the engineering curriculum is currently a challenge for curriculum designers. Industry standards and the EHEA demand to tackle professional competencies as an integral part of university instruction so that engineers respond more effectively to industry standards. In Spanish engineering degrees, this is a new task that requires curriculum designers and coordinators to find procedures to integrate professional skills.
The present work has described a proposal in accordance with the Tuning project to integrate a defined set of competencies into the Bachelor Degree in Computing Engineering at the Barcelona School of Informatics (UPC). Based on the general university framework and on competency maps, we propose a model to integrate competency contents into degree subjects. Maps organize those contents into competency dimensions, which are further defined into three-level objectives. These specific objectives can be more appropriately fitted into course contents. Additionally, course coordinators and lecturers can more easily attempt practice activities and assessment tasks.

Our model also provides a global competency map, which is a useful tool for curriculum designers to control the complete development of competencies throughout the degree. This allows to devise a procedure based on iteration to refine the process of assigning objectives as we complete our global map. Although we have only implemented our proposal in an initial phase, we believe that our model becomes flexible enough to provide integral development of professional skills in engineering curricula [13].

\section{RELATED WORK}

Professional and soft skills are becoming more and more critical, particularly in information technologies, due to constant increases in interconnectivity, multidisciplinarity, and globalization. Consequently, various studies have recently focused on teaching and assessing these skills (see, for instance, the comprehensive review by Shuman et al. in [14]).

Early experiences in areas such as communications, teamwork, conflict resolution, and ethics had successfully been introduced within some undergraduate programs as specific courses [15]. American universities have adjusted educational objectives of undergraduate programs (specially in engineering) to address some of these soft skills. Particular efforts include their implementation using PBL [16], in cocurricular and extracurricular activities [17] or by means of dedicated seminars [18].

Nevertheless, there are few studies that aim at introducing these skills uniformly throughout the curricula, by integrating it into existing technical courses. Among these, two references stand out: first, the experience at the Civil and Structural Engineering Department, Universiti Kebangsaan Malaysia integrating professional practices into their four-year program in civil engineering [19]; second, the work developed at the Delft University of Technology (The Netherlands) introducing a skills line into the curriculum [20].

Other recent references around the world address the inclusion of professional skills in their curricula as specific courses or using small groups. All of them stress the importance of raising awareness of these concerns as indicated by means of student polls [16, 21, 22]. 


\section{REFERENCES}

[1] CDIO Syllabus. Edward F. Crowley. MIT, 2001. http://www.cdio.org.. Accessed 25 April 2014.

[2] Accreditation Criteria. Accreditation Board for Engineering and Technology, Inc. http://www.abet.org. Accessed 25 April 2014

[3] http://tuning.unideusto.org/tuningal. Accessed 25 April 2014.

[4] García, J.; Sánchez, F. and Gavaldà, R. November 2007. "Recomendaciones para el Diseño de una Titulación de Grado en Informática." IEEE RITA, Revista Iberoamericana de Tecnologías del Aprendizaje. Vol 2 (2).

[5] Faulkner, X.; Daniels, M. and Newman, I. "The Open Ended Group Project: A Way of Including Diversity in the IT Curriculum." In Trajkovski, G. (ed). 2006. Diversity in Information Technology Education: Issues and Controversies. Information Science Publishing, pp. 166-195.

[6] Sánchez, F.; Sancho, M-R. and Herrero, J.R.. "Organización y Gestión de una Titulación del EEES.” In XVII Jornadas de Enseñanza Universitaria de la Informática. July 2011. JENUI' 2011. Sevilla. pp 161-168.

[7] Bloom, B.S.; Engelhart, M.D.; Furst, E.J.; Hill, W.H. and Krathwohl, D.R. 1956. Taxonomy of Educational Objectives: Handbook I, The Cognitive Domain. New York: David McKay.

[8] Cajander, A.; Daniels, M. and von Konsky, B.R. "Development of Professional Competencies in Engineering Education." In IEEE Frontiers in Education Conference. 12-15 October 2011. Proceedings of the $41^{\text {st }}$ ASEE/IEEE Frontiers in Education Conference. pp. S1C-1S1C-5.

[9] García, M.J.; Fernández, L.; Terrón, M.J. and Blanco, Y. "Métodos de Evaluación para las Competencias Generales más Demandadas en el Mercado Laboral.” In XIV Jornadas de Enseñanza universitaria de la Informática. July 2008. JENUI'2008. Granada. pp 265-272.

[10] Reave, L. 2004. "Technical Communication Instruction in Engineering Schools: A Survey of Top-Ranked US and Canadian Schools." Journal of Business and Technical Communication, Vol 18 (4), pp. 452-490.

[11] López, D. and Ramírez, A. 2012. "Marco para el Desarrollo de la Competencia Transversal Comunicación Eficaz." TICAI (TICS Aplicadas para el aprendizaje de la Ingenieria). IEEE Education Society, pp. 9-16.

[12] Riemer, M. J. 2007. "Communication Skills for the 21st Century Engineer" Global J. of Engng. Educ., Vol.11, No.1.

[13] Martín, C. (In press). "Assessing an Appropriate Attitude towards Work in Engineering Education." International Journal of Engineering Education.

[14] Shuman, L.J.; Besterfield-Sacre, M. and McGourty, J. 2005. "The ABET Professional Skills - Can They be Taught? Can They Be Assessed?" Journal of Engineering Education. Vol 94(1), pp 41-56.

[15] Lamp, J.; Keen, C. and Urquhart, C. "Integrating Professional Skills into the Curriculum." In Proceedings of the First Australasian Conference on Computer Science Education. Sydney, Australia. pp 309-316.

[16] Chidthachack, S.; Schulte, M.A.; Ntow, F.D.; Lin, J.-L.and Moore, T.J. "Engineering Students Learn ABET Professional Skills: A Comparative Study of Project-Based-Learning (PBL) versus Traditional Students." In ASEE North Midwest Section Conference. 17-18 October 2013. Proceedings of the ASEE North Midwest Section Conference. Fargo, North Dakota.

[17] Fisher, D. R. "Educating Engineers for the 21st century: A Framework for Skill Development through Co-Curricular and Extracurricular Involvement.” Massachusetts Institute of Technology, Engineering Systems Division, 2013. URI: http://hdl.handle.net/1721.1/81118. Accessed 25 April 2014.

[18] Rover, D.; Mickelson, S.; Hartmann, B.; Rehmann, C.; Jacobson, D.; Kaleita, A.; Shelley, M.; Laingen, M.; Ryder, A. and Bruning, M. "Engineer of 2020 Outcomes and the Student Experience." In Frontiers in Education Conference, 23-26 October. 2013. Proceedings of the $43^{\text {rd }}$ ASEE/IEEE Frontiers in Education Conference. pp 140 146.

[19] Mutalib, A.A.; Baharom, S.; Razali, S.F.M.; Hamid, R.; Othman S.A. and Badaruzzaman, W.H.W.. "Development of Professional Competencies in the CSED Curriculum at UKM", in Procedia Social and Behavioral Sciences 102 (2013) 74 - 79

[20] Janssen, M.; van Daalen, C.E.; Elling, R.; Ubacht, J. and Bouwmans, I. April 2010. "Lessons Learned from Introducing a Skills Line into a Systems Engineering Curriculum." Transforming Engineering Education: Creating Interdisciplinary Skills for Complex Global Environments. IEEE. pp.1-13

[21] Mohan, A.; Merle, D.; Jackson, C.; Lannin, J. and Nair, S.S. 2010. "Professional Skills in the Engineering Curriculum." IEEE Transactions on Education. Vol. 53 (4).

[22] Gider, F.; Likar, B.; Kern, T. and Miklavcic, D. 2012 "Implementation of a Multidisciplinary Professional Skills Course at an Electrical Engineering School." IEEE Transactions on Education. Vol. 55 (3). 